\title{
Procalcitonin-Guided Antibiotic Treatment in Lower Respiratory Tract Infections
}

\author{
Merih Kalamanoğlu Balcı', Baran Balcan², Şehnaz Olgun Yıldızeli², Berrin Ceyhan² \\ ${ }^{1}$ Department of Pulmonary Medicine, İstanbul Yeni Yüzyıl University School of Medicine, İstanbul, Turkey \\ ${ }^{2}$ Department of Pulmonary Medicine, Marmara University School of Medicine, İstanbul, Turkey
}

\section{Cite this article as: Kalamanoğlu Balıı M, Balcan B, Olgun Yıldızeli Ş, Ceyhan B. Procalcitonin-Guided Antibiotic Treatment in Lower Respiratory Tract Infections. JAREM 2018; 8(2): 72-8.}

\begin{abstract}
Objective: Procalcitonin (PCT), C-reactive protein (CRP), and leukocyte count are important host response biomarkers to determine the presence of infection. The aim of the present study was to evaluate the usefulness of PCT with other markers in lower respiratory tract infections.

Methods: A total of 78 patients with community-acquired pneumonia (CAP), chronic obstructive pulmonary disease (COPD) exacerbations, and healthy controls were evaluated. Baseline serum levels of PCT and CRP and leukocyte counts were assessed and repeated on day 7 of antibiotic treatment.

Results: Procalcitonin levels and absolute neutrophil counts (ANCs) were higher in the CAP and COPD groups than in the control group. In the CAP and COPD exacerbation groups, the leukocyte count, ANC, and CRP and PCT levels decreased on day 7 of the treatment ( $p<0.001)$. In the CAP group, the baseline PCT levels were correlated with leukocyte counts $(r=0.495, p<0.005)$, ANCs $(r=0.426, p<0.019)$, and CRP levels $(r=0.515$, $\mathrm{p}<0.004)$. In receiver operating characteristic curve analysis, PCT threshold $>0.12 \mathrm{ng} / \mathrm{mL}$ had a sensitivity of $70.4 \%$ and specificity of $68.7 \%$, and CRP threshold $>22.9 \mathrm{mg} / \mathrm{L}$ had a sensitivity of $85.2 \%$ and specificity of $75.0 \%$.
\end{abstract}

Conclusion: Procalcitonin is a useful marker to determine the initiation of antibiotic therapy and can also be used to cease the treatment.

Keywords: Procalcitonin, C-reactive protein, lower respiratory tract infection

\section{INTRODUCTION}

Lower respiratory tract infections (LRTIs) include a broad array of diseases, including community-acquired pneumonia (CAP), ventilator-associated pneumonia, chronic obstructive pulmonary disease (COPD) exacerbations, and tuberculosis (1). Pneumonia is the leading cause of hospitalization worldwide $(1,2)$. CAP mortality ranges between $1 \%$ and $48 \%$ in European countries (2). Identifying the gold standard technique for the differential diagnosis of LRTI is often problematic, and the causative organisms can be detected in only 10\%-20\% of patients with respiratory infections $(3,4)$. The leading cause of antibiotic prescription is pneumonia, and the unnecessary use of antibiotics may contribute to increased bacterial resistance $(5,6)$.

The assessment of the severity and prognosis of LRTI can be easier with the help of biomarkers. There are some validated scores such as pneumonia severity index and CURB 65 (confusion, uremia, respiratory rate, blood pressure, and age: $\geq 65$ years) that have direct impacts on the severity of disease $(6,7)$. The use of these scores can be helpful in noticing the severity of disease. (8).
In recent years, the importance of the use of blood markers such as procalcitonin (PCT) in combination with these scores has been defined (9). PCT, a protein comprising 116 amino acids, is the pro-peptide of the hormone, calcitonin (CT) (10). The release of PCT in inflammation has been directly induced by microbial toxins such as endotoxin, or indirectly induced via a humoral or cellmediated host response, e.g., interleukin (IL)-1 $\beta$, tumor necrosis factor- $\alpha$, and IL-6 $(11,12)$. An increased level of PCT is related to respiratory tract infections, particularly to pneumonia (13). Moreover, an increased level of PCT is related to the severity of bacterial infection (14). Although PCT levels were highest in typical bacterial infection, the levels did not predict the microbiological response (15).

Infective and non-infective reasons can cause acute exacerbations of COPD. Bacterial infections are the most common causes of exacerbations; however, antibiotics have been used without differentiating infective or non-infective exacerbation (16). The decision of antibiotic use in acute exacerbations of COPD is significant to avoid bacterial resistance (17). PCT has been used as an important biomarker in the detection of acute exacerbations of COPD (18). 
C-reactive protein (CRP), an acute phase reactant, has been used for the diagnosis of various infectious and inflammatory diseases (19). CRP measurement is inexpensive and widely available. Reportedly, CRP levels are higher in patients with CAP than in healthy controls (20).

In the present study, we aimed to evaluate the serum level of PCT in LRTIs and to correlate PCT with other biomarkers such as CRP and white blood cell (WBC) count. Moreover, we aimed to prove that the serum level of PCT is a useful biomarker in the differential diagnosis of LRTIs and to assess the response to treatment to help clinicians.

\section{METHODS}

\section{Subjects}

A total of 78 patients were included in the present study and were categorized into three groups: 30 patients with CAP, 24 patients with COPD exacerbation, and 24 controls. This was a prospective, observational diagnostic accuracy study. The study was approved by the Marmara University Ethics Committee (Approval number: B.30.2.MAR.0.01 00.02/AEK273). Written informed consent was obtained from all subjects. The patients were categorized based on the American Thoracic Society criteria as CAP and COPD acute exacerbation. The patients with sepsis, cancer, or aspiration pneumonia; who were pregnant; or $<18$ years or $>85$ years were excluded.

\section{Study Design}

At entry to the study, demographic and clinical data were recorded. In addition to physical examination and chest radiography, laboratory tests were performed, including blood cell counts and the measurement of erythrocyte sedimentation rate (ESR), serum CRP, and $P C T$, and the routine assessment of blood chemistry. Microbiological tests were performed on sputum and blood cultures. The patients with CAP or COPD exacerbation were re-evaluated on day 7. Blood samples for the analysis of PCT levels were centrifuged, and serum was stored at $-80^{\circ} \mathrm{C}$.

PCT levels were measured using the quantitative Kryptor PCT test kit (Brahms, Hennigsdorf, Germany). This assay has the advantage of using time-resolved amplified cryptate emission technology and is based on polyclonal anti-CT and monoclonal anticatacalcin antibodies that bind CT and its precursor molecules. This is a functional test with a sensitivity of $0.06 \mu \mathrm{g} / \mathrm{L}$ (14). The time required for the test is $19 \mathrm{~min}$, and the results are routinely obtained after $1 \mathrm{~h}$ using $20-50 \mu \mathrm{L}$ of serum. A turbidimetric method (BN ProSpec System, Dade BEHRING) was used to measure serum CRP levels.

\section{Statistical Analysis}

Descriptive results are presented as mean \pm SD. The comparisons of the mean values among the groups and among dif- ferent days for each group were performed by the analysis of variance (ANOVA) followed by Tukey's test. For the comparisons of the groups, ANOVA test was used. The associations between parameters were evaluated using Pearson's correlation coefficient. A p-value of $<0.05$ was considered as statistically significant. The receiver operating characteristic (ROC) curve analysis was performed to determine the cut-off value of PCT for the diagnosis of CAP. The data were analyzed by the Statistical Packages for Social Sciences version 21.0 (IBM Corp.; Armonk, NY, USA).

Table 1. Demographic characteristics of the patients with lower respiratory tract infections

\begin{tabular}{l|c|c|c|}
\hline Groups & $\begin{array}{c}\text { Patients } \\
(\mathbf{n})\end{array}$ & $\begin{array}{c}\text { Age } \\
\text { (mean } \pm \text { ) }\end{array}$ & $\begin{array}{c}\text { Female/ } \\
\text { male }\end{array}$ \\
\hline CAP & 30 & $56 \pm 16$ & $9 / 21$ \\
\hline COPD exacerbations & 24 & $64 \pm 7$ & $13 / 11$ \\
\hline Controls & 24 & $64 \pm 8$ & $13 / 11$ \\
\hline Total & 78 & & \\
\hline CAP: community-acquired pneumonia; COPD: Chronic obstructive pulmonary disease
\end{tabular}

Table 2. Demographic characteristics of the patients with lower respiratory tract infections

\begin{tabular}{|l|c|c|c|c|}
\hline \multirow{2}{*}{} & \multicolumn{3}{|c|}{ Infectious patients } & \\
\cline { 2 - 4 } & $\begin{array}{c}\text { CAP } \\
(\text { mean } \pm)\end{array}$ & $\begin{array}{c}\text { COPD } \\
\text { exacerbation } \\
(\text { mean } \pm)\end{array}$ & Control & P \\
\hline WBC $\left(\times 10^{9} / \mathrm{L}\right)$ & $15.3 \pm 6.43$ & $9.73 \pm 2.44$ & $6.75 \pm 2.11$ & $<0.001$ \\
\hline ANC $\left(\times 10^{9} / \mathrm{L}\right)$ & $12.12 \pm 6.35$ & $7.3 \pm 1.97$ & $3.2 \pm 1.73$ & $<0.001$ \\
\hline CRP $(\mathrm{mg} / \mathrm{L})$ & $149 \pm 117$ & $19.5 \pm 26.3$ & $3 \pm 1.16$ & $<0.001$ \\
\hline PCT $(\mathrm{ng} / \mathrm{mL})$ & $4.26 \pm 11.97$ & $0.206 \pm 0.397$ & $0.042 \pm 2.12$ & $<0.001$ \\
\hline ANC: absolute neutrophil count; COPD: Chronic obstructive pulmonary \\
disease; $\mathrm{CRP}:$ C-reactive protein; PCT: pro-calcitonin; WBC: white blood cell
\end{tabular}

Table 3. Baseline serum CRP and pro-calcitonin concentrations, absolute neutrophil and white blood cell counts in patients with community-acquired pneumonia (CAP) or exacerbations of chronic obstructive pulmonary disease (COPD)

\begin{tabular}{|c|c|c|c|}
\hline Groups & $\begin{array}{l}\text { Patients } \\
\text { (n) }\end{array}$ & $\begin{array}{c}\text { Age } \\
(\text { mean } \pm)\end{array}$ & $\begin{array}{c}\text { Female/ } \\
\text { male }\end{array}$ \\
\hline WBC $\left(\times 10^{\circ} / \mathrm{L}\right)$ & $15.3 \pm 6.43$ & $9.73 \pm 2.44$ & $<0.001$ \\
\hline ANC ( $\left.\times 10^{\circ} / L\right)$ & $12.12 \pm 6.35$ & $7.3 \pm 1.97$ & $<0.001$ \\
\hline CRP (mg/L) & $149 \pm 117$ & $19.5 \pm 26.3$ & $<0.001$ \\
\hline РCТ (ng/mL) & $4.26 \pm 11.97$ & $0.206 \pm 0.397$ & $<0.003$ \\
\hline \multicolumn{4}{|c|}{$\begin{array}{l}\text { ANC: absolute neutrophil count; CAP: community acquired pneumonia; } \\
\text { COPD: Chronic obstructive pulmonary disease; CRP: C-reactive protein, PCT: } \\
\text { pro-calcitonin WBC: white blood cell }\end{array}$} \\
\hline
\end{tabular}




\section{RESULTS}

We studied 78 patients: 30 patients with CAP, 24 patients with COPD exacerbation, and 24 control subjects.

Table 1 shows the baseline characteristics of the study population. All patients with COPD exacerbation or CAP received empirical

Table 4. Absolute neutrophil and leukocyte counts, and serum CRP and pro-calcitonin concentrations in patients with community-acquired pneumonia (CAP), chronic obstructive pulmonary disease (COPD) at baseline and on $7^{\text {th }}$ day of treatment

\begin{tabular}{|c|c|c|c|c|}
\hline & & Baseline & Day 7 & $p$ \\
\hline \multirow{4}{*}{ CAP } & PCT $(\mathrm{ng} / \mathrm{mL})$ & $4.26 \pm 11.97$ & $0.256 \pm 0.056$ & $<0.001$ \\
\cline { 2 - 6 } & CRP $(\mathrm{mg} / \mathrm{L})$ & $149 \pm 117$ & $23.08 \pm 31.31$ & $<0.001$ \\
\hline \multirow{4}{*}{ COPD } & WBC $\left(\times 10^{9} / \mathrm{L}\right)$ & $15.3 \pm 6.43$ & $7.68 \pm 2.24$ & $<0.001$ \\
\cline { 2 - 6 } & ANC $\left(\times 10^{9} / \mathrm{L}\right)$ & $12.12 \pm 6.35$ & $5.0 \pm 2.23$ & $<0.001$ \\
\hline \multirow{4}{*}{} & PCT $(\mathrm{ng} / \mathrm{ml})$ & $0.206 \pm 0.397$ & $0.074 \pm 0.05$ & $<0.01$ \\
\cline { 2 - 6 } & CRP $(\mathrm{mg} / \mathrm{L})$ & $19.5 \pm 26.3$ & $7.43 \pm 8.75$ & $<0.001$ \\
\hline & WBC $\left(\times 10^{9} / \mathrm{L}\right)$ & $9.73 \pm 2.44$ & $7.83 \pm 2.15$ & $<0.001$ \\
\hline & ANC $\left(\times 10^{9} / \mathrm{L}\right)$ & $7.3 \pm 1.97$ & $5.26 \pm 1.89$ & $<0.001$ \\
\hline
\end{tabular}

ANC: absolute neutrophil count; CAP: community-acquired pneumonia; COPD: Chronic obstructive pulmonary disease; CRP: C-reactive protein; PCT: pro-calcitonin; WBC: white blood cell count antibiotic therapy. Two sputum cultures from the CAP group were positive for Streptococcus pneumoniae and Haemophilus influenza. One patient with CAP died, and the baseline serum PCT concentration of this patient was $0.51 \mathrm{ng} / \mathrm{mL}$.

Table 5. Correlation of pro-calcitonin with other biomarkers elevated in serum during infection

\begin{tabular}{|c|c|c|c|}
\hline & \multicolumn{3}{|c|}{ РCT (ng/mL) } \\
\hline \multirow{6}{*}{ CAP } & \multirow[t]{2}{*}{ WBC (x 109/L) } & $r$ & 0.495 \\
\hline & & $p$ & $<0.001$ \\
\hline & \multirow[t]{2}{*}{ ANC (x 109/L) } & $r$ & 0.426 \\
\hline & & $p$ & $<0.01$ \\
\hline & \multirow[t]{2}{*}{ CRP (mg/L) } & r & 0.515 \\
\hline & & $p$ & $<0.001$ \\
\hline \multirow{6}{*}{ COPD } & \multirow[t]{2}{*}{ WBC (x 109/L) } & r & 0.456 \\
\hline & & $p$ & $<0.01$ \\
\hline & \multirow[t]{2}{*}{ ANC (x 109/L) } & r & 0.414 \\
\hline & & $\mathrm{p}$ & $<0.05$ \\
\hline & \multirow[t]{2}{*}{ CRP (mg/L) } & $r$ & 0.424 \\
\hline & & $p$ & $<0.05$ \\
\hline
\end{tabular}

a

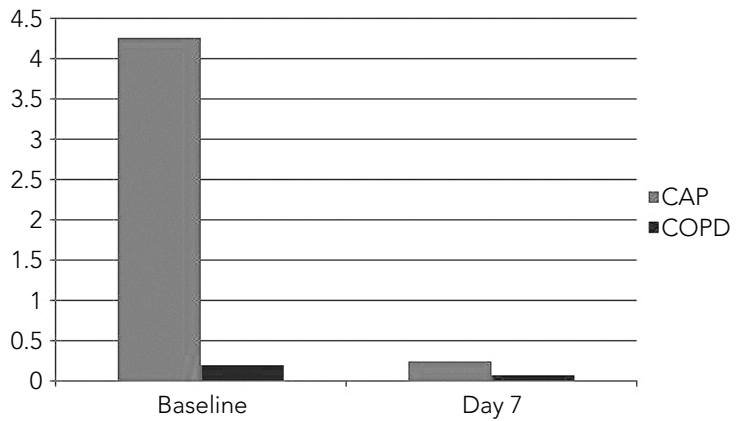

c

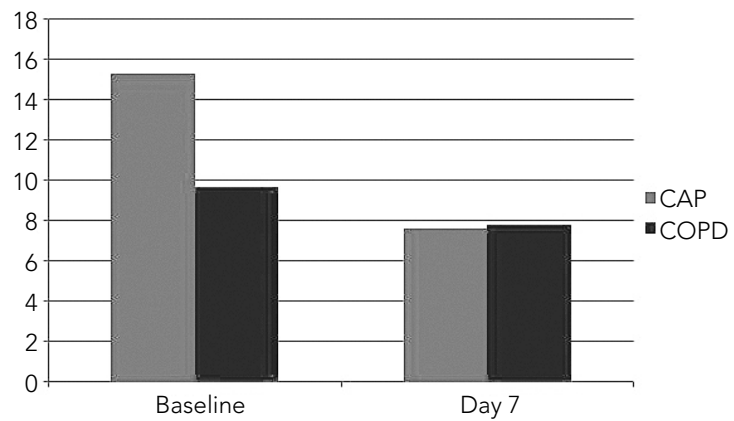

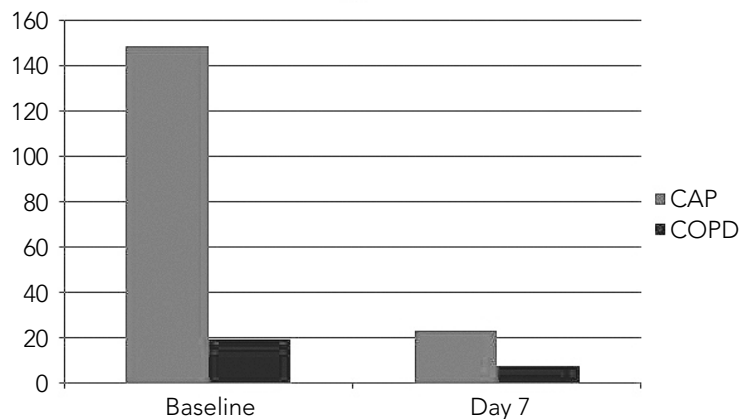

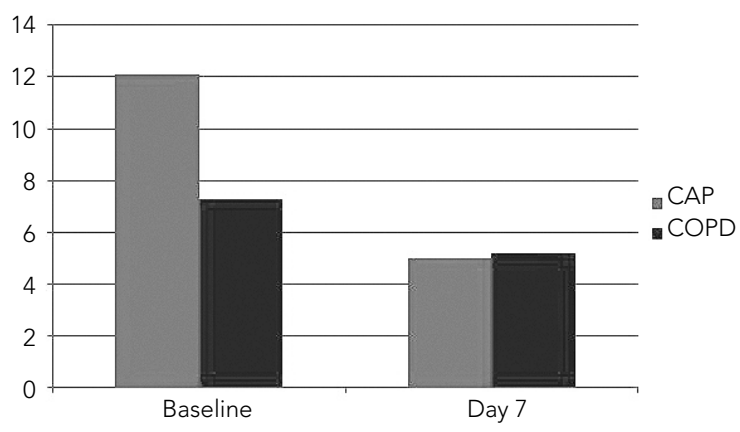

Figure 1. a-d. (a) Difference of serum level of procalcitonin at baseline and on day 7 of antibiotic treatment. (b) Difference of serum level of C-reactive protein at baseline and on day 7 of antibiotic treatment. (c) Difference of serum level of white blood cell count at baseline and on day 7 of antibiotic treatment. (d) Difference of serum level of absolute neutrophil count at baseline and on day 7 of antibiotic treatment 


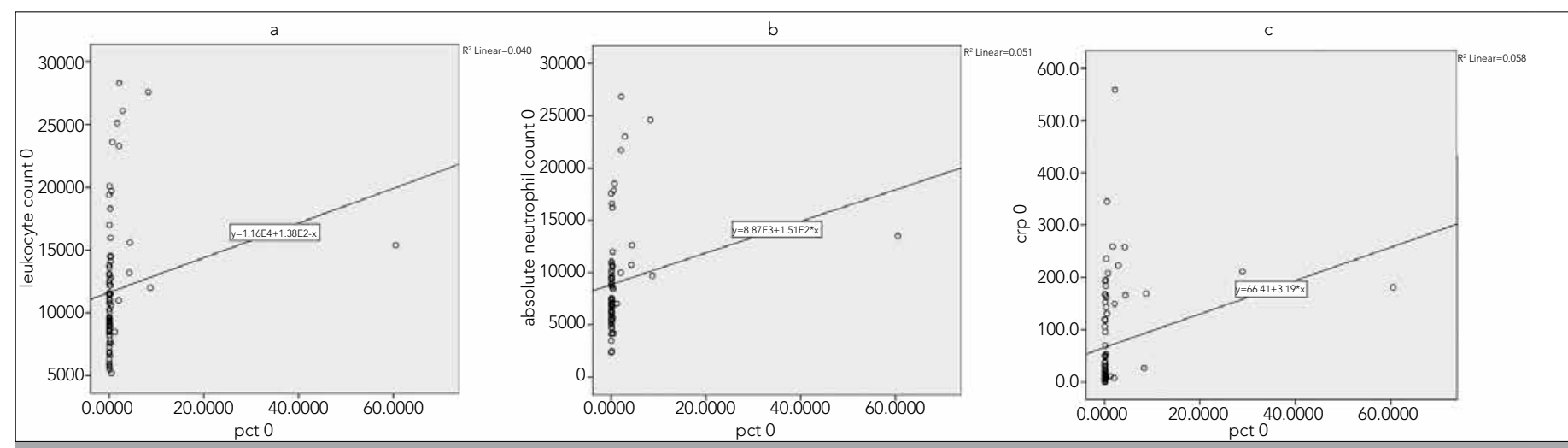

Figure 2. a-c. (a) Correlation analysis between procalcitonin and white blood cell count. (b) Correlation analysis between procalcitonin and absolute neutrophil count. (c) Correlation analysis between procalcitonin and C-reactive protein

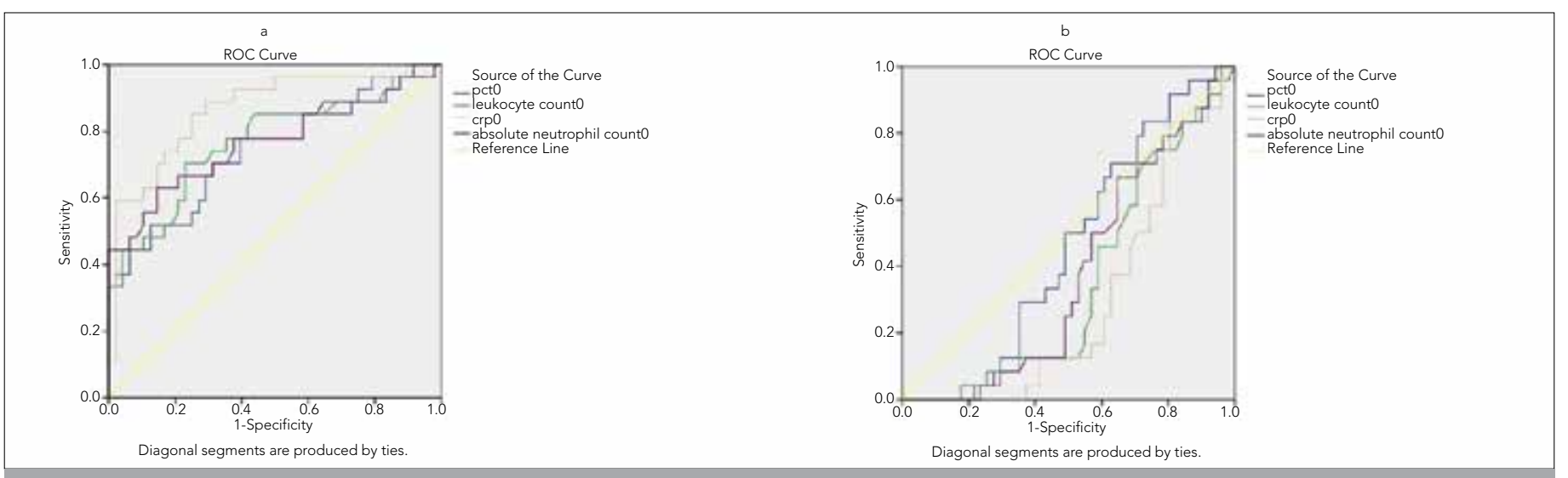

Figure 3. a, b. (a) ROC curve analysis of procalcitonin, C-reactive protein, white blood cell count, and absolute neutrophil count in patients with CAP. (b) ROC curve analysis of procalcitonin, C-reactive protein, white blood cell count, and absolute neutrophil count in patients with COPD

At baseline, the PCT and CRP levels, apart from leukocyte and absolute neutrophil counts (ANCs), were significantly higher in the infective (CAP and COPD exacerbation) patients than in healthy individuals (Table 2). In the infectedpatients (CAP/COPD exacerbations), all evaluated inflammatory markers (PCT, CRP, ESR, WBC, and ANC) were higher in the CAP group than in the COPD exacerbation group (Table 3 ).

The evaluated parameter values at the baseline and on day 7 of the treatment are summarized in Table 4 and Figure 1. The CRP and PCT levels, leukocyte counts, and ANCs were significantly lower after seven days of the antibiotic treatment than those at baseline for the CAP and COPD exacerbation groups.

For both groups combined, the baseline PCT levels were significantly positively correlated with leukocyte counts, ANCs, and CRP levels (Figure 2). Table 5 summarizes the correlation analysis of PCT with the evaluated biomarkers for the patients with CAP and COPD. In CAP and COPD exacerbation groups, there was a positive and linear relationship between PCT and CRP, ANC, and WBC.

The ROC curve was identified to determine the optimum values of the evaluated blood markers. PCT threshold $>0.12 \mathrm{ng} /$
$\mathrm{mL}$ had a sensitivity of $70.4 \%$ and specificity of $68.7 \%$ (area under the curve (AUC): 0.742, 95\% Cl: 0.620-0.863), CRP threshold $>22.9 \mathrm{mg} / \mathrm{L}$ had a sensitivity of $85.2 \%$ and specificity of $75.0 \%$ (AUC: $0.867,95 \% \mathrm{Cl}$ : 0.777-0.956), WBC threshold $11.45\left(\times 10^{9} / \mathrm{L}\right.$ ) had a sensitivity of $70.4 \%$ and specificity of $77.4 \%$ (AUC: 0.767 , 95\% Cl: 0.647-0.887), and ANC threshold $7.98(\times 10 \% / L)$ had a sensitivity of $70.1 \%$ and specificity of $67.8 \%$ (AUC: $0.757,95 \%$ $\mathrm{Cl}$ : 0.613-0.851) whileidentifying the patients with pneumonia (Figure 3a). Moreover, the same calculations and ROC curve analysis were performed to determine the threshold value in COPD exacerbations; however, only the sensitivity and specificity of PCT were slightly $>50 \%$, and they were $<50 \%$ for the others (Figure $3 b$ ).

\section{DISCUSSION}

In the present study, we observed that the baseline PCT levels at diagnosis were higher in the patients with LRTIs than in healthy individuals. At admission to a hospital, it is possible to distinguish the infective patients from non-infective ones when suspected with LRTIs. The PCT levels were higher in patients with CAP than in patients with COPD. On day 7 of the antibiotic treatment, we observed that there was a statistically significant decrease in the levels of PCT and other biomarkers. There was a positive and linear correlation between PCT and CRP, WBC, and ANC in the 
patients with CAP and COPD. Using ROC curve analysis, it was possible to calculate the cut-off values of the patients with CAP for PCT, CRP, WBC, and ANC.

In our study, we observed that PCT and other inflammatory marker levels were higher in the patients with LRTI than in noninfectious cases. Previously, WBC count and CRP were routinely used in the diagnosis and follow-up of infections. However, PCT has not been routinely used in clinical practice. As observed in our study and defined in current studies, PCT can be safely used in the diagnosis of bacterial infections that cannot be defined in culture (21-23). Previously, it has been reported that PCT can differentiate bacterial infections from viral ones; therefore, its use can prevent the unnecessary uses of antibiotics by evaluating the serum PCT levels in patients with lower respiratory infection (24).

The elevated levels of PCT are related with the existence and severity of bacterial infection; therefore, high PCT alerts clinicians to immediately initiate antibiotic treatment $(25,26)$. Moreover, during the discrimination of bacterial infections, it is more useful than CRP because CRP can be elevated in any inflammatory process, but PCT is more specific to bacterial infections (27).

In our study, the baseline PCT levels were significantly higher in the CAP group than in COPD exacerbation group. Viral agents are responsible for $75 \%$ of respiratory tract infections. In addition, in COPD exacerbations, viruses may be responsible for infection as much as bacteria; however, CAP is most commonly caused due to bacterial infections. Therefore, a higher level of PCT in CAP than that in COPD exacerbation is an expected result.

In our study, we observed a significant decrease at the end of day 7 of the antibiotic treatment in the CAP and COPD groups. The serum level of PCT guidance has an advantage over the standard therapy of LRTIs in the decision to immediately initiate antibiotic therapy $(18,28)$. Prkno et al. (9) calculated that the median length of antibiotic therapy is six days in the PCT-guided group and eight days in the non-PCT-guided group. With the evaluation of the serum level of PCT, the decision to discontinue antibiotic therapy will be easier, and the unnecessary use of antibiotics can be avoided $(9,29,30)$. With the use of such biomarkers, clinicians have an advantage to avoid the prolonged course of broadspectrum antibiotics resulting in antibiotic resistance (31). An increased antimicrobial resistance is associated with an increased mortality and longer periods of hospitalizations (32). Moreover, the cessation of antibiotic treatment according to serum PCT levels has benefits on the long-term follow-up period; there is a significant decrease in re-hospitalization and exacerbation rates $(18,33)$.

With ROC curve analysis, we tried to calculate a cut-off value for the determination of infection in the patients suspected with CAP and COPD. In the CAP group, the patients who had PCT of $>0.12 \mathrm{ng} / \mathrm{mL}$ and $C R P$ of $>22.9 \mathrm{mg} / \mathrm{L}$ were the infective ones. Nouvenne et al. defined the higher levels of CRP $(61 \mathrm{mg} / \mathrm{L})$ and PCT $(0.22 \mathrm{ng} / \mathrm{mL})$ for the diagnosis of pneumonia. In our study, they were not able to define a cut-off value for CRP and PCT in patients with COPD. van Vugt et al. (34) reported a threshold value of $30.0 \mathrm{mg} / \mathrm{L}$ for CRP (closer to our cut-off value) in pneumonia. In our study, the threshold values of CRP and PCT were lower for the diagnosis of pneumonia; this result may be due to the lower number of co-morbidities in our study group. In our study, the threshold value of CRP has a better diagnostic value than that of PCT, and similar results were reported by a few studies. On the other hand, Hirakata et al. (35) reported that PCT is a better biomarker than CRP in CAP.

The major drawback of the study was that all patients could not be evaluated on a daily basis. The serum level of biomarkers could be grouped according to the co-morbidities; then, the elevation in the levels of CRP and PCT can be more strongly associated with infection. The study would have given better sensitivity and specificity results if it included a larger population size.

\section{CONCLUSION}

Serum PCT levels increased in the early phase of LRTIs. Serum PCT can be used in the diagnosis of pneumonia, and serum PCT level is a useful biomarker for the diagnosis of infective acute exacerbations of COPD. The results demonstrate that PCT has almost equal accuracy for the detection of pneumonia as CRP. However, further studies are needed to confirm these observations.

Ethics Committee Approval: Ethics committee approval was received for this study from the Ethics Committee of Marmara University (Approval number: B.30.2.MAR.0.01 00.02/AEK-273).

Informed Consent: Written informed consent was obtained from patients who participated in this study.

Peer-review: Externally peer-reviewed.

Author Contributions: Concept - M.K.B., B.C.; Design - M.K.B., B.C.; Supervision - M.K.B., B.C.; Resources - M.K.B., B.C.; Materials - M.K.B., B.C.; Data Collection and/or Processing - M.K.B., B.C.; Analysis and/or Interpretation - M.K.B., B.B., Ş.O.Y.; Literature Search - M.K.B., B.B.; Writing Manuscript - M.K.B., B.B.; Critical Review - M.K.B., B.B., Ş.O.Y., B.C.

Conflict of Interest: The authors have no conflicts of interest to declare.

Financial Disclosure: The authors declared that this study has received no financial support.

\section{REFERENCES}

1. Mizgerd JP. Acute lower respiratory tract infection. N Engl J Med. 2008;358:716-27. [CrossRef]

2. Welte T, Torres A, Nathwani D. Clinical and economic burden of community-acquired pneumonia among adults in Europe. Thorax. 2012;67:71-9. [CrossRef]

3. Niederman MS, Mandell LA, Anzueto A, Bass JB, Broughton WA, Campbell GD, Dean N, File T, Fine MJ, Gross PA, et al. Guidelines 
for the management of adults with community-acquired pneumonia. Diagnosis, assessment of severity, antimicrobial therapy, and prevention. Am J Respir Crit Care Med. 2001;163:1730-54. [CrossRef]

4. Irfan M, Farooqi J, Hasan R. Community-acquired pneumonia. Curr Opin Pulm Med. 2013;19:198-208. [CrossRef]

5. Wenzel RP. The antibiotic pipeline--challenges, costs, and values. N Engl J Med. 2004;351:523-6. [CrossRef]

6. Marras TK, Gutierrez C, Chan CK. Applying a prediction rule to identify low-risk patients with community-acquired pneumonia. Chest. 2000;118:1339-43. [CrossRef]

7. Lim WS, van der Eerden MM, Laing R, Boersma WG, Karalus N, Town GI, Lewis SA, Macfarlane JT. Defining community acquired pneumonia severity on presentation to hospital: an international derivation and validation study. Thorax. 2003;58:377-82. [CrossRef]

8. Chalmers JD, Mandal P, Singanayagam A, Akram AR, Choudhury G, Short PM, Hill AT. Severity assessment tools to guide ICU admission in community-acquired pneumonia: systematic review and metaanalysis. Intensive Care Med. 2011;37:1409-20. [CrossRef]

9. Prkno A, Wacker C, Brunkhorst FM, Schlattmann P. Procalcitoninguided therapy in intensive care unit patients with severe sepsis and septic shock--a systematic review and meta-analysis. Crit Care. 2013;17:R291. [CrossRef]

10. Le Moullec JM, Jullienne A, Chenais J, Lasmoles F, Guliana JM, Milhaud G, Moukhtar MS. The complete sequence of human preprocalcitonin. FEBS Lett. 1984;167:93-7. [CrossRef]

11. Muller B, Becker KL. Procalcitonin: how a hormone became a marker and mediator of sepsis. Swiss Med Wkly. 2001;131:595-602.

12. Muller $B$, Becker $K L$, Schachinger $H$, Rickenbacher PR, Huber PR, Zimmerli W, Ritz R. Calcitonin precursors are reliable markers of sepsis in a medical intensive care unit. Crit Care Med. 2000;28:977-83. [CrossRef]

13. Uzzan B, Cohen R, Nicolas P, Cucherat M, Perret GY. Procalcitonin as a diagnostic test for sepsis in critically ill adults and after surgery or trauma: a systematic review and meta-analysis. Crit Care Med. 2006;34:1996-2003. [CrossRef]

14. Weidner W, Wagenlehner FM. Re: Procalcitonin as a diagnostic marker for sepsis: a systematic review and meta-analysis. Eur Urol. 2014;66:178. [CrossRef]

15. Christ-Crain M, Jaccard-Stolz D, Bingisser R, Gencay MM, Huber PR, Tamm M, Muller B. Effect of procalcitonin-guided treatment on antibiotic use and outcome in lower respiratory tract infections: clusterrandomised, single-blinded intervention trial. Lancet. 2004;363:6007. [CrossRef]

16. Papi A, Bellettato CM, Braccioni F, Romagnoli M, Casolari $P$, Caramori G, Fabbri LM, Johnston SL. Infections and airway inflammation in chronic obstructive pulmonary disease severe exacerbations. Am J Respir Crit Care Med. 2006;173:1114-21. [CrossRef]

17. Gilbert D, Gelfer G, Wang L, Myers J, Bajema K, Johnston M, Leggett $J$. The potential of molecular diagnostics and serum procalcitonin levels to change the antibiotic management of community-acquired pneumonia. Diagn Microbiol Infect Dis. 2016. [CrossRef]

18. Stolz D, Christ-Crain M, Bingisser R, Leuppi J, Miedinger D, Muller C, Huber P, Muller B, Tamm M. Antibiotic treatment of exacerbations of COPD: a randomized, controlled trial comparing procalcitonin-guidance with standard therapy. Chest. 2007;131:9-19. [CrossRef]
19. Malo O, Sauleda J, Busquets X, Miralles C, Agusti AG, Noguera A. [Systemic inflammation during exacerbations of chronic obstructive pulmonary disease]. Arch Bronconeumol. 2002;38:172-6. [CrossRef]

20. Marik PE. The clinical features of severe community-acquired pneumonia presenting as septic shock. Norasept II Study Investigators. J Crit Care. 2000;15:85-90. [CrossRef]

21. Dymicka-Piekarska V, Wasiluk A. [Procalcitonin (PCT), contemporary indicator of infection and inflammation]. Postepy Hig Med Dosw (Online). 2015;69:723-8. [CrossRef]

22. Polzin A, Pletz M, Erbes R, Raffenberg M, Mauch $H$, Wagner S, Arndt G, Lode H. Procalcitonin as a diagnostic tool in lower respiratory tract infections and tuberculosis. Eur Respir J. 2003;21:939-43. [CrossRef]

23. Hedlund J, Hansson LO. Procalcitonin and C-reactive protein levels in community-acquired pneumonia: correlation with etiology and prognosis. Infection. 2000;28:68-73. [CrossRef]

24. Sridharan P, Chamberlain RS. The efficacy of procalcitonin as a biomarker in the management of sepsis: slaying dragons or tilting at windmills? Surg Infect (Larchmt). 2013;14:489-511. [CrossRef]

25. Akpinar S, Rollas K, Alagoz A, Segmen F, Sipit T. Performance evaluation of MR-proadrenomedullin and other scoring systems in severe sepsis with pneumonia. J Thorac Dis. 2014;6:921-9.

26. Brunkhorst FM, Al-Nawas B, Krummenauer F, Forycki ZF, Shah PM. Procalcitonin, C-reactive protein and APACHE II score for risk evaluation in patients with severe pneumonia. Clin Microbiol Infect. 2002;8:93-100. [CrossRef]

27. Simon L, Gauvin F, Amre DK, Saint-Louis P, Lacroix J. Serum procalcitonin and C-reactive protein levels as markers of bacterial infection: a systematic review and meta-analysis. Clin Infect Dis. 2004;39:20617. [CrossRef]

28. National Clinical Guideline C. National Institute for Health and Care Excellence: Clinical Guidelines. Pneumonia: Diagnosis and Management of Community- and Hospital-Acquired Pneumonia in Adults. London: National Institute for Health and Care Excellence (UK) Copyright (c) National Clinical Guideline Centre, 2014.; 2014.

29. Schuetz P, Muller B, Christ-Crain M, Stolz D, Tamm M, Bouadma L, Luyt CE, Wolff M, Chastre J, Tubach F, et al. Procalcitonin to initiate or discontinue antibiotics in acute respiratory tract infections. Cochrane Database Syst Rev. 2012Cd007498.

30. Assink-de Jong E, de Lange DW, van Oers JA, Nijsten MW, Twisk JW, Beishuizen A. Stop Antibiotics on guidance of Procalcitonin Study (SAPS): a randomised prospective multicenter investigator-initiated trial to analyse whether daily measurements of procalcitonin versus a standard-of-care approach can safely shorten antibiotic duration in intensive care unit patients--calculated sample size: 1816 patients. BMC Infect Dis. 2013;13:178. [CrossRef]

31. Dellinger RP, Levy MM, Rhodes A, Annane D, Gerlach H, Opal SM, Sevransky JE, Sprung CL, Douglas IS, Jaeschke R, et al. Surviving Sepsis Campaign: international guidelines for management of severe sepsis and septic shock, 2012. Intensive Care Med. 2013;39:165228. [CrossRef]

32. Cosgrove SE. The relationship between antimicrobial resistance and patient outcomes: mortality, length of hospital stay, and health care costs. Clin Infect Dis. 2006;42 Suppl 2:S82-9. [CrossRef]

33. Vollenweider DJ, Jarrett H, Steurer-Stey CA, Garcia-Aymerich J, Puhan MA. Antibiotics for exacerbations of chronic obstructive pulmonary disease. Cochrane Database Syst Rev. 2012;12:Cd010257. [CrossRef] 
34. van Vugt SF, Broekhuizen BD, Lammens C, Zuithoff NP, de Jong PA, Coenen S, leven M, Butler CC, Goossens H, Little P, et al. Use of serum $C$ reactive protein and procalcitonin concentrations in addition to symptoms and signs to predict pneumonia in patients presenting to primary care with acute cough: diagnostic study. BMJ. 2013;346:f2450. [CrossRef]
35. Hirakata Y, Yanagihara K, Kurihara S, Izumikawa K, Seki M, Miyazaki $Y$, Kohno S. Comparison of usefulness of plasma procalcitonin and C-reactive protein measurements for estimation of severity in adults with community-acquired pneumonia. Diagn Microbiol Infect Dis. 2008;61:170-4. [CrossRef] 